Reviu Akuntansi dan Bisnis Indonesia, Vol. 3 No. 1, Hlm: 102-123, Juli 2019

Website: http://journal.umy.ac.id/index.php/rab

\title{
Pengaruh Kinerja Keuangan, Ukuran Perusahaan, dan Good Corporate Governance Terhadap Pengungkapan Sustainability Report pada Perusahaan Manufaktur yang Terdaftar dalam Bursa Efek Indonesia
}

\author{
Rotua Aprilya Tobing ${ }^{*}$; Zuhrotun; Rusherlistyani \\ Universitas Pembangunan Nasional "Veteran” Yogyakarta \\ I N F O A R T I K E L

\section{Kata Kunci:} \\ Sustainability Report, \\ Profitabilitas, Leverage, \\ Ukuran Perusahaan, \\ Komite Audit dan Dewan \\ Komisaris Independen. \\ Jenis Artikel: \\ Penelitian Kuantitatif \\ ${ }^{*}$ Correspondence: \\ tobingapril@gmail.com \\ A B S T R A K \\ Tujuan penelitian ini adalah menganalisis pengaruh profitabilitas, leverage, \\ ukuran perusahaan, komite audit dan dewan komisaris independen \\ terhadap pengungkapan sustainability report. Populasi penelitian adalah \\ perusahaan manufaktur yang terdaftar di Bursa Efek Indonesia pada \\ periode tahun 2015-2017. Dalam teknik pengambilan sampel penelitian ini \\ menggunakan metode purposive sampling dan diperoleh 30 sampel. \\ Model analisis yang digunakan dalam penelitian ini adalah analisis \\ deskriptif, uji asumsi klasik, dan analisis regresi linear berganda. Hasil dari \\ penelitian ini menunjukkan bahwa profitabilitas dan ukuran perusahaan \\ berpengaruh terhadap pengungkapan sustainability report. Sedangkan, \\ leverage, komite audit dan dewan komisaris independen tidak berpengaruh \\ terhadap pengungkapan sustainability report pada perusahaan manufaktur \\ yang terdaftar di Bursa Efek Indonesia.
}

(C) 2019 RAB. Published by Universitas Muhammadiyah Yogyakarta

\section{PENDAHULUAN}

Pada hakikatnya tujuan utama dari sebuah perusahaan adalah memperoleh keuntungan sebesar-besarnya. Dewasa ini tuntutan terhadap perusahaan semakin besar. Perusahaan diharapkan tidak hanya mementingkan kepentingan manajemen dan pemilik modal (investor dan kreditor) tetapi juga karyawan, konsumen serta masyarakat. Namun, pandangan tersebut kini bergeser kearah yang lebih kompleks yaitu bagaimana masyarakat sebagai pengguna hasil produksi perusahaan mengakui kredibilitas dari perusahaan tersebut. Kegiatan pengelolaan perusahaan saat ini tidak hanya berdasarkan aspek ekonomi tetapi juga mempertimbangkan aspek sosial. Daniri (2014) menyatakan bahwa tuntutan terhadap perusahaan untuk memberikan informasi yang transparan, organisasi yang akuntabel serta tata kelola perusahaan atau good corporate governance (GCG) semakin memaksa perusahaan untuk memberikan informasi mengenai aktivitas sosialnya. Salah satu konsekuensi implementasi prinsip-prinsip GCG adalah bahwa perusahaan tidak dapat hanya memikirkan kinerja keuangan saja tetapi juga harus melakukan penilaian atas kinerja sosial dan lingkungannya. Perusahaan kemudian mengungkapkan aktivitas tanggung jawab sosial dan lingkungan melalui sustainability report untuk memenuhi kepentingan stakeholder.

Nurrahman dan Sudarno (2013) menggaris bawahi bahwa berkembangnya isu mengenai corporate social responsibility (CSR) dan laporan keberlanjutan (sustainability report) perusahaan menjadi sorotan utama terhadap perannya pada lingkungan. Sustainability report belakangan ini telah menjadi isu utama perusahaan sehingga tujuan perusahaan kini tidak hanya tertuju pada 
pencapaian keuntungan. Konsep tersebut muncul karena tuntutan dan harapan masyarakat tentang peran perusahaan dalam masyarakat. Laporan keberlanjutan (sustainability report) merupakan bentuk laporan yang bersifat sukarela (voluntary) sebagai bentuk tanggung jawab sosial dan lingkungan. Sustainability report sangat diperlukan agar stakeholders termasuk masyarakat, mengetahui segala bentuk tanggung jawab perusahaan kepada masyarakat dan lingkungan. Adanya aturan tegas yang mewajibkan perusahaan untuk melakukan tanggung jawab sosial dan lingkungan, mendorong manajer perusahaan untuk melakukan pengungkapan sustainability report. Namun adanya alasan tersebut, tidak membuat semua perusahaan di Indonesia melakukan pengungkapan sustainability report, tidak adanya single definition dari sustainability report yang mampu diterima secara global, maupun bagaimana seharusnya bentuk format dari sustainability report itu sendiri menjadi alasan utama tidak setiap perusahaan mau melakukan pengungkapan. Alasan lainnya yaitu manajer perusahaan mempunyai tingkat inisiatif yang berbeda dalam hal pengungkapan sustainability report, serta penyusunannya memerlukan biaya yang banyak. Sustainability report erat kaitannya dengan kinerja keuangan dan ukuran perusahaan.

Kesadaran perusahaan untuk mengungkapkan laporan yang bersifat sukarela

seperti laporan keberlanjutan masih sangat kurang. Dari top 100 perusahaan yang terdaftar di Bursa Efek Indonesia (BEI), baru 30\% perusahaan yang membuat Sustainability Report (SR), sedangkan dari tahun 2000 sampai saat ini, baru ada 97 perusahaan yang melakukan reporting melalui Global Report Initiative (GRI). Kesadaran perusahaan untuk mengungkapkan laporan yang bersifat sukarela seperti laporan keberlanjutan masih sangat kurang. Ada beberapa faktor yang membuat perusahaan enggan membuat sustainability report. Pertama yaitu perusahaan tidak transparan dalam menjalankan bisnisnya, dan tidak memiliki komitmen menjadi perusahaan good corporate governance. Faktor kedua yaitu perusahaan menganggap sustainability report sebagai sebuah biaya tambahan. Nasir (2017) menyatakan dengan pendapatnya bahwa melalui laporan berkelanjutan, perusahaan didorong mengungkapkan secara transparan pelaksanaan tanggung jawab sosial dan lingkungannya.

Beberapa alasan kuat mengapa sustainability report dirasakan semakin perlu untuk diimplementasikan secara konkrit khususnya perusahaan yang memiliki dampak besar terhadap alam dan sosial adalah sebagai berikut, pertama, untuk menunjukkan kepedulian organisasi bisnis terhadap masyarakat dan lingkungan. Kedua, stakeholder eksternal semakin kaya pemikiran dalam menetapkan kepercayaan kepada perusahaan baik dalam hal produk maupun kinerja secara keseluruhan serta kekuatan komunikasi yang dibangun oleh perusahaan dengan stakeholder eksternal sangat dipengaruhi oleh kepedulain perusahaan untuk mengakomodasi kepentingan mereka. Ketiga, reputasi atau nama baik perusahaan tidak hanya berdasarkan kemampuan dalam menghasilkan laba dan produk yang berkualitas melainkan juga kepedulian perusahaan terhadap lingkungan alam dan sosial bahakan investor untuk mengambil keputusan investasi tidak lagi terpusat pada analisis yang bersifat teknikal melainkan juga fundamental secara luas yaitu kepedulian perusahaan untuk menerapkan sustainability report. Keempat, dengan menerapkan sustainability report, perusahaan memiliki kemampuan bersaing lebih tinggi karena memiliki kualitas sumber daya manusia yang mumpuni dan teknologi ramah lingkungan serta menguatkan pasar melalui hubungan yang solid dengan pelanggan, supplier, masyarakat, LSM, dan lembaga-lembaga keuangan penunjang.

\section{TINJAUAN LITERATUR DAN PERUMUSAN HIPOTESIS}

Beberapa faktor yang dapat mempengaruhi pengungkapan sustainability report adalah kinerja keuangan yang diproksikan dengan profitabilitas dan leverage, ukuran perusahaan, good corporate governance yang diproksikan dengan komite audit dan dewan komisaris independen. 
Kinerja keuangan

Kinerja keuangan merupakan gambaran dari pencapaian keberhasilan perusahaan dapat diartikan sebagai hasil yang telah dicapai atas berbagai aktivitas yang telah dilakukan. Dapat dijelaskan bahwa kinerja keuangan adalah suatu analisis yang dilakukan untuk melihat sejauh mana suatu perusahaan telah melaksanakan dengan menggunakan aturan-aturan pelaksanaan keuangan secara baik dan benar (Fahmi, 2012). Menurut Rudianto (2013) kinerja keuangan adalah hasil atau prestasi yang telah dicapai oleh manajemen perusahaan dalam mengelola aset perusahaan secara efektif selama periode tertentu. Kinerja keuangan yang digunakan dalam penelitian ini adalah profitabilitas dan leverage.

Profitabilitas

Rasio profitabilitas merupakan salah satu indikator penting untuk menilai kinerja suatu perusahaan. Menurut Sartono (2012) profitabilitas adalah kemampuan perusahaan memperoleh laba dalam hubungannya dengan penjualan, total aktiva maupun modal sendiri. Dengan demikian bagi investor jangka panjang akan akan sangat berkepentingan dengan analisis profitabilitas ini, misalnya bagi pemegang saham akan melihat keuntungan yang benar-benar akan diterima dalam bentuk dividen. Profitabilitas adalah rasio untuk menilai kemampuan perusahaan dalam mencari keuntungan. Rasio ini juga memberikan ukuran tingkat efektifitas manajemen suatu perusahaan. Hal ini ditunjukan oleh laba yang dihasilkan dari penjualan dan pendapatan investasi (Kasmir, 2015).

Leverage

Leverage adalah mengukur seberapa besar perusahaan dibiayai dengan utang. Penggunaan utang yang terlalu tinggi akan membahayakan perusahaan karena perusahaan akan masuk dalam kategori extreme leverage (utang ekstrim) yaitu perusahaan terjebak dalam tingkat utang yang tinggi dan sulit untuk melepaskan beban utang tersebut (Fahmi, 2015). Menurut Kasmir (2015) leverage merupakan rasio yang digunakan untuk mengukur sejauh mana aktiva perusahaan dibiayai dengan utang. Artinya berapa besar beban utang yang ditanggung perusahaan dibandingkan dengan aktivanya. Dalam arti luas dikatakan bahwa rasio leverage digunakan untuk mengukur kemampuan perusahaan untuk membayar seluruh kewajibannya, baik jangka pendek maupun jangka panjang apabila perusahaan dibubarkan (dilikuidasi).

\section{Ukuran Perusahaan}

Menurut Brigham dan Houston (2014) ukuran perusahaan merupakan ukuran besar kecilnya sebuah perusahaan yang ditunjukan atau dinilai oleh total asset, total penjualan, jumlah laba, beban pajak dan lain-lain. Seperti pendapat Torang (2012) ukuran organisasi adalah menentukan jumlah anggota yang berhubungan dengan pemilihan cara pengendalian kegiatan dalam usaha mencapai tujuan

\section{Good Corporate Governance}

Menurut Sutedi (2013) good corporate governance adalah suatu proses dan struktur yang digunakan oleh organ perusahaan (pemegang saham, dewan pengawas) untuk meningkatkan keberhasilan usaha dan akuntabilitas perusahaan guna mewujudkan nilai pemegang saham dalam jangka panjang dengan tetap memperhatikan kepentingan stakeholder lainnya, berlandaskan peraturan perundang - undangan dan nilai - nilai etika.

Good corporate governance yang digunakan dalam penelitian ini adalah komite audit dan dewan komisaris independen. 
Komite Audit

Semakin banyak jumlah anggota komite audit maka koordinasi komite audit akan semakin baik sehingga dapat melaksanakan pengawasan terhadap manajemen dengan lebih efektif dan diharapkan dapat mendukung peningkatan publikasi informasi sosial dan lingkungan yang dilakukan oleh perusahaan. Hal ini dikarenakan salah satu hal yang mendukung good corporate governance adalah dengan mempublikasikan sustainability report. Good corporate governance merupakan suatu proses atau sistem yang bertujuan meningkatkan nilai dan keberlangsungan perusahaan dalam jangka panjang dengan tetap memperhatikan kepentingan seluruh stakeholders. Pengawasan komite audit mendorong pelaksanaan GCG yang efektif.

Dewan Komisaris Independen

Dewan komisaris independen merupakan anggota dewan komisaris yang bukan merupakan anggota manajemen atau memiliki keterkaitan erat dengan perusahaan yang diharapkan dapat menciptakan keseimbangan kepentingan perusahaan dan stakeholders yang terlibat. Komisaris independen diharapkan tidak terpengaruh oleh manajemen sehingga dapat mendorong perusahaan untuk mengungkapkan informasi yang lebih luas. Keberadaan dewan komisaris independen sebagai bagian dari penerapan good corporate governance akan mendorong kemungkinan perusahaan melakukan pengungkapan lebih untuk para stakeholder, salah satunya pengungkapan sustainability report.

Kerangka Konseptual

Kerangka konseptual ini menjelaskan bahwa variabel independen (X) merupakan variabel bebas yang dapat mempengaruhi dan menyebabkan terjadinya perubahan pada variabel dependen (Y). Variabel independen dalam penelitian ini meliputi: profitabilitas (X1), leverage (X2), ukuran perusahaan (X3), komite audit (X4), dan dewan komisaris independen (X5. Variabel dependen (Y) yang digunakan dalam penelitian ini adalah pengungkapan sustainability report. Alasan penyusunan hipotesis adalah berdasarkan penjelasan yang sudah dipaparkan sebelumnya, maka kerangka pemikiran teoritis yang dapat menunjukkan hubungan antar variabel seperti tampak pada gambar 2.1 berikut ini :

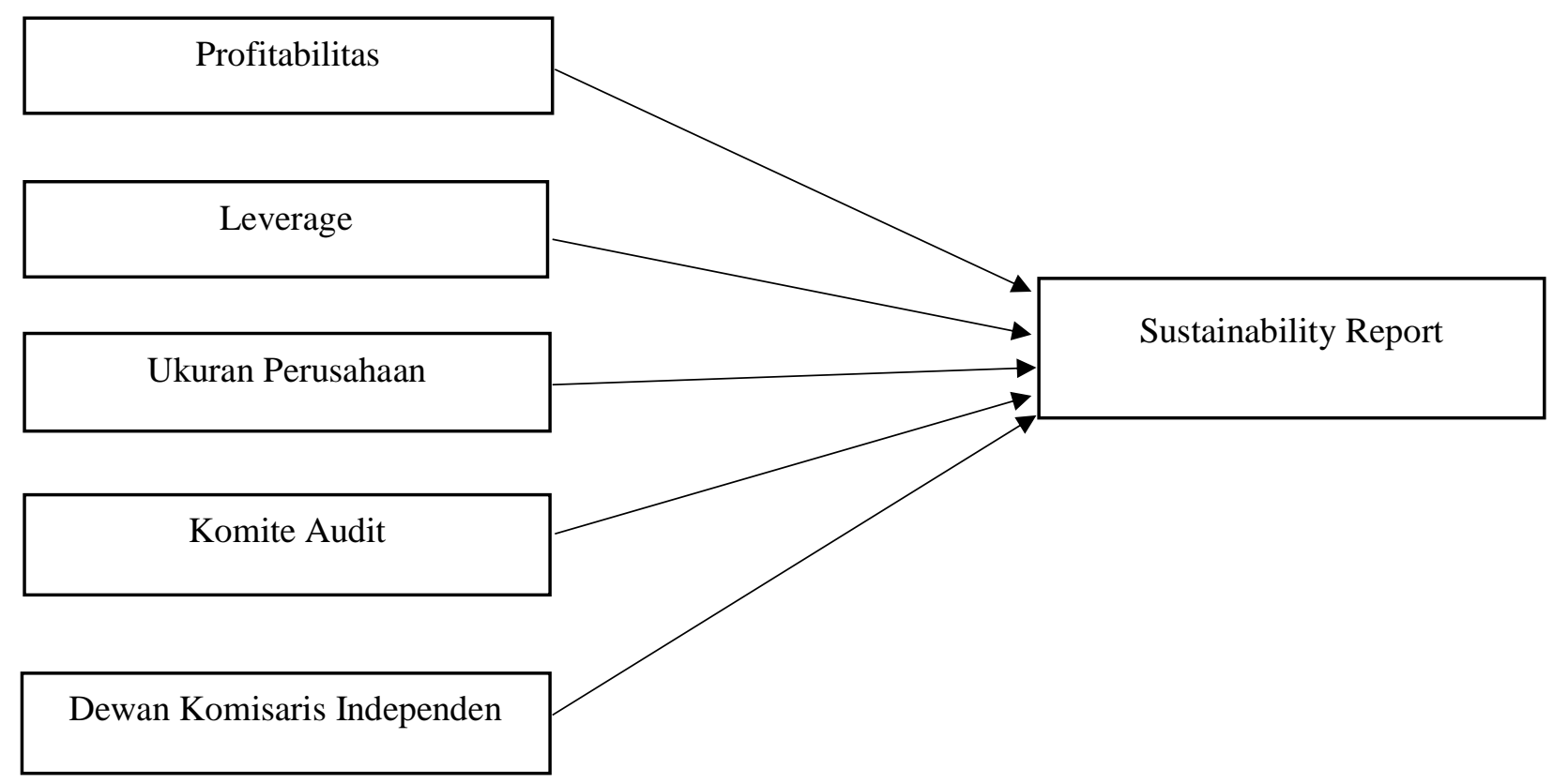

Gambar 1.1 Kerangka Konseptual 

berikut :

Berdasarkan kerangka konseptual di atas, maka dapat dinyatakan hipotesis penelitian sebagai

$\boldsymbol{H}_{\boldsymbol{I}} \quad$ : Profitabilitas berpengaruh terhadap pengungkapan sustainability report.

$\boldsymbol{H}_{2} \quad$ : Leverage berpengaruh terhadap pengungkapan sustainability report.

$\boldsymbol{H}_{3}$ : Ukuran Perusahaan berpengaruh terhadap pengungkapan sustainability report.

$\boldsymbol{H}_{4} \quad$ : Komite audit berpengaruh terhadap pengungkapan sustainability report.

$\boldsymbol{H}_{5}$ : Dewan komisaris independen berpengaruh terhadap pengungkapan sustainability report.

\section{METODE PENELITIAN}

Populasi dan sampel

Populasi dalam penelitian adalah perusahaan manufaktur yang terdaftar di Bursa Efek Indonesia selama periode 2015 hingga 2017. Pemilihan dimulai pada tahun 2015 karena tahun tersebut merupakan tahun awal pengungkapan sustainability report. Perbedaan tahun penelitian dimaksudkan untuk megetahui kinerja keuangan satu tahun yang akan datang. Berdasarkan populasi tersebut akan ditentukan sampel sebagai objek penelitian. Sampel dalam penelitian ini diperoleh dengan menggunakan metode purposive sampling Adapun kriteria yang digunakan adalah :

1. Perusahaan yang menerbitkan annual report antara tahun 2015-2017.

2. Mempublikasikan sustainability report antara tahun 2015-2017.

Variabel Dependen

Sustainability Report

Menurut Gunawan (2010) definisi operasional dari pengungkapan sustainability report adalah dalam aturan yang telah ditetapkan berupa laporan yang berdiri sendiri, meskipun masih banyak pengimplementasian sustainability report yang diungkapkan bersamaan dengan laporan tahuan suatu perusahaan. Sustainability report diukur dari pengungkapan yang terkait dengan tanggung jawab sosial dan lingkungan berdasarkan indikator Global Reporting Initiative (GRI) level G4 tahun 2013. Metode content analysis digunakan untuk untuk mengukur pengungkapan sustainability report perusahaan. Metode ini dilakukan dengan memberikan checklist atas pengungkapan sustainability report perusahaan yang sesuai dengan indikator yang ditetapkan oleh Global Reporting Initiative (GRI). Apabila perusahaan mengungkapkan item maka diberi nilai 1 dan apabila tidak mengungkapkan maka diberi nilai 0 .

Variabel Independen

Kinerja Keuangan

Menurut Wibowo (2014) kinerja keuangan merupakan gambaran mengenai kondisi dan keadaan dari suatu perusahaan yang dianalisis dengan alat-alat analisis keuangan sehingga dapat diketahui baik buruknya kondisi keuangan dan prestasi keuangan sebuah perusahaan dalam waktu tertentu. Kinerja keuangan yang digunakan dalam penelitian ini adalah leverage dan profitabilitas. 
Profitabilitas

Menurut Hanafi (2012) profitabilitas merupakan rasio yang mengukur kemampuan perusahaan menghasilkan keuntungan pada tingkat penjualan, aset, dan modal saham yang tertentu. Profitabilitas dalam penelitian ini diukur dengan return on assets (ROA) yang dihitung dengan laba bersih setelah pajak dibagi dengan total aktiva.

Rumus Return On Assets sebagai berikut :

Leverage

$$
\text { Profitabilitas }=\frac{\text { Laba Bersih }}{\text { Total Aset }}
$$

Menurut Sjahrial (2009) leverage adalah penggunaan aktiva dan sumber dana oleh perusahaan yang memiliki biaya tetap (beban tetap) berarti sumber dana yang berasal dari pinjaman karena memiliki bunga sebagai beban tetap dengan maksud agar meningkatkan keuntungan potensial pemegang saham. Leverage dalam penelitian ini diukur dengan debt to equity ratio (DER), yaitu merupakan rasio yang digunakan untuk menilai hutang dengan ekuitas.

Rumus Debt to Equity Ratio:

$$
\text { Leverage }=\frac{\text { Total Hutang }}{\text { Total Modal }}
$$

Ukuran perusahaan

Menurut Brigham dan Houston (2014) ukuran perusahaan merupakan ukuran besar kecilnya sebuah perusahaan yang ditunjukan atau dinilai oleh total asset, total penjualan, jumlah laba, beban pajak dan lain-lain. Ukuran perusahaan menggambarkan besar kecilnya perusahaan. Ukuran perusahaan dalam penelitian ini diukur dengan logaritma natural dari total aset yang dimiliki perusahaan.

\section{Good Corporate Governance}

Good Corporate Governance merupakan tata kelola perusahaan yang menjelaskan hubungan antara berbagai partisipan dalam perusahaan yang menentukan arah kinerja perusahaan (Haruman, 2008). Good Corporate Governance yang digunakan dalam penelitian ini adalah komite audit dan dewan komisaris independen.

Komite audit

Komite audit adalah komite yang dibentuk oleh dan bertanggung jawab kepada Dewan Komisaris dalam melaksanakan tugas dan fungsi Dewan Komisaris (Makhdalena, 2011). Komite audit dalam penelitian ini diukur dengan menggunakan jumlah rapat anggota komite audit dalam setahun.

Dewan Komisaris Independen

Dewan komisaris independen merupakan anggota dewan komisaris yang tidak terafiliasi dengan direksi, anggota komisaris lainnya dan pemegang saham pengendali, serta bebas dari hubungan bisnis atau hubungan lainnya yang dapat mempengaruhi kemampuannya untuk bertindak independen demi kepentingan perusahaan (Makhdalena, 2012). Dewan komisaris independen dalam penelitian ini diukur dengan jumlah anggota dewan komisaris independen dibagi jumlah seluruh anggota dewan komisaris dalam suatu perusahaan. 
Rumus Dewan Komisaris Independen:

\section{Komisaris Independen \\ $\overline{\text { Anggota Dewan Komisaris }}$}

Bagian ini memuat rancangan penelitian atau desain penelitian, sasaran dan target penelitian (populasi dan sampel), teknik pengumpulan data, model penelitian, dan teknik analisis. Pada bab ini juga dituliskan secara jelas bagaimana penelitian dilakukan. Untuk penelitian studi kasus (termasuk penelitian non-positivism/kualitatif), bagian ini meliputi: jenis penelitian, obyek, data, dan teknik/tahapan analisis. Untuk penelitian survei, bagian ini berisi: jenis penelitian, populasi dan teknik pengambilan sampel, jenis dan sumber data, instrumen penelitian, dan teknik analisis data.

\section{HASIL DAN PEMBAHASAN}

Data Peneltian

Penelitian ini menggunakan data Jenis data sekunder, yang diperoleh secara tidak langsung melalui media perantara. Menurut Sugiyono (2014) data sekunder adalah sumber data yang tidak secara langsung memberikan data kepada pengumpul data, misalnya lewat orang lain atau dokumen. Data sekunder yang digunakan adalah sustainability report dan annual report periode tahun 2015-2017 yang didapat dari website perusahaan atau website BEI (http://www.idx.co.id).

Tabel 3.1 Hasil Pemilihan Sampel

\begin{tabular}{lll}
\hline No & Keterangan & Jumlah \\
\hline 1. & Populasi : Perusahaan manufaktur yang & 142 \\
& terdaftar di BEI mulai dari tahun 2015-2017. & \\
& Sampel : Perusahaan manufaktur yang tidak & $(22)$ \\
menerbitkan annual report tahun 2015-2017. & $(110)$ \\
& Sampel : Perusahaan manufaktur yang tidak \\
menerbitkan sustainability report tahun 2015- & \\
2017. & 10 \\
\hline
\end{tabular}

Sumber: Data sekunder, diolah 2019

Jumlah perusahaan manufaktur yang terdaftar di Bursa Efek Indonesia (BEI) selama periode 2015-2017 berjumlah 142 perusahaan. Adapun perusahaan yang dijadikan sampel dalam penelitian ini adalah sebagai berikut:

Tabel 3.2 Daftar Sampel

\begin{tabular}{lll}
\hline No & Kode Perusahaan & Nama Perusahaan \\
\hline 1. & SMGR & Semen Indonesia (Persero) Tbk \\
2. & WTON & Wijaya Karya Beton \\
3. & MLBI & Multi Bintang Indonesia Tbk \\
4. & TKIM & Pabrik Kertas Tjiwi Kimia Tbk \\
5. & CPIN & Charoen Pokphand Indonesia Tbk \\
6. & ASII & Astra International Tbk \\
7. & INTP & Indocement Tunggal Prakarsa Tbk \\
8. & UNVR & Unilever Indonesia Tbk \\
9. & SMCB & Holcim Indonesia Tbk \\
10. & GMFI & PT Garuda Maintenance Facility Aero Asia Tbk \\
\hline
\end{tabular}

Sumber : Data sekunder, diolah 2019 


\section{Statistik Deskriptif}

Analisis statistik deskriptif dalam penelitian ini meliputi rata-rata (mean), standar deviasi, nilai maksimal, nilai minimum dan jumlah data penelitian. Berikut ini hasil analisis statistik deskriptif data pada masing-masing variabel:

Tabel 3.3 Statistik Deskriptif

\begin{tabular}{llllll}
\hline & $\mathbf{N}$ & Minimum & Maximum & Mean & Std. Deviation \\
\hline Profitabilitas & 30 & .001 & .527 & .13109 & .141603 \\
Leverage & 30 & .154 & 2.655 & 1.28796 & .737140 \\
UP & 30 & 14.728 & 26.412 & $2.26345 \mathrm{E} 1$ & 3.149976 \\
KA & 30 & 4 & 33 & 10.43 & 8.709 \\
DKI & 30 & .000 & .571 & .34069 & .176008 \\
SR & 30 & .088 & .692 & .30366 & .177743 \\
Valid N (listwise) & 30 & & & & \\
\hline
\end{tabular}

Sumber : Data sekunder, diolah 2019

Uji Normalitas

Uji normalitas bertujuan untuk menguji apakah dalam model regresi, variabel dependen maupun independen atau keduanya terdistribusi secara normal atau tidak normal (Ghozali, 2013). Distribusi normal dalam penelitian ini dideteksi dengan menggunakan uji kolmogorovsmirnov (K-S). Adapun hasil pengujian dapat dilihat pada Tabel 3.4 sebagai berikut :

Tabel 3.4 Hasil Uji Normalitas

\begin{tabular}{lll} 
& & Unstandardized Residual \\
\hline $\mathrm{N}$ & & 30 \\
Normal Parameters & & .0000000 \\
& Mean & .09545400 \\
Most Extreme Differences & Std. Deviation & .087 \\
& Absolute & .081 \\
& Positive & -.087 \\
Kolmogorov-Smirnov Z & Negative & .474 \\
Asymp. Sig. (2-tailed) & & .978 \\
a. Test distribution is Normal. & &
\end{tabular}

Sumber : Data sekunder, diolah 2019

Uji Heteroskedastisitas

Uji Heteroskedastisitas dilakukan untuk menguji apakah dalam sebuah model regresi terjadi ketidaksamaan variance dari residual atas suatu pengamatan ke pengamatan lain (Ghozali, 2013). Model regresi yang baik adalah model yang bebas dari masalah heterokedastisitas. Adapun hasil heterokedastisidas ditunjukkan pada Tabel 3.5 sebagai berikut :

Tabel 3.5 Hasil Uji Heterokedastisitas Sebelum diubah ke LN

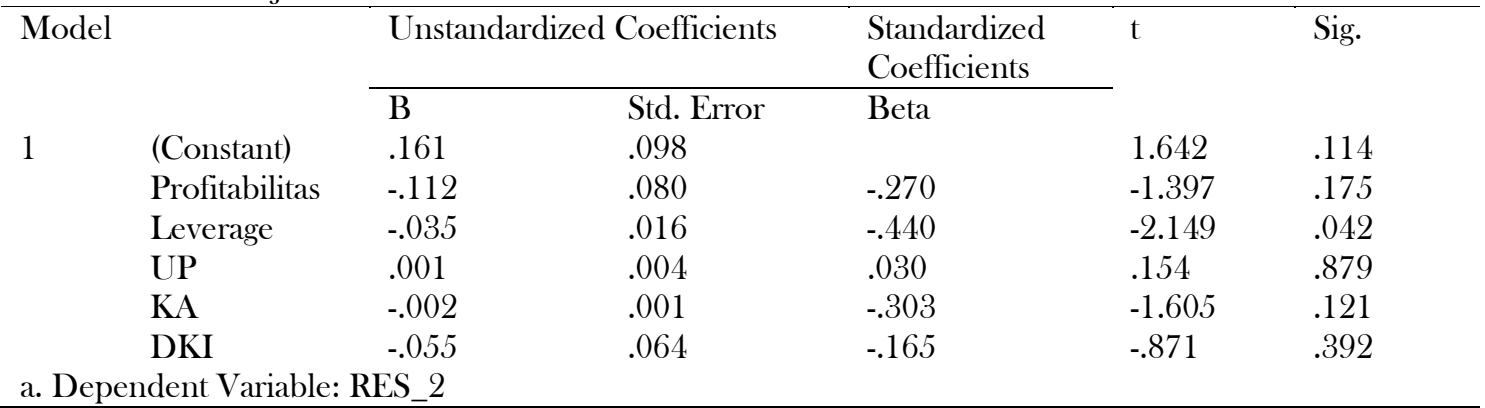


Sumber : Data sekunder, diolah 2019

Tabel 3.5 menunjukkan hasil pengujian heterokedastisitas dengan uji gletser. Dari hasil uji heterokedastisitas menunjukan bahwa variabel profitabilitas, ukuran perusahaan, komite audit dan dewan komisaris independen mempunyai nilai signifikansi diatas 0,05 yang artinya tidak ada masalah heterokedastisidas sedangkan variabel leverage mengalami masalah heterokedastisitas yaitu nilai signifikansi dibawah 0,05 dengan nilai 0.042. Oleh karena itu, peneliti melakukan transformasi data ke bentuk lain yaitu logaritma natural $(\ln )$ maka diperoleh data sebagai berikut :

Tabel 3.6 Hasil Uji Heterokedastisidas Sesudah diubah ke LN

\begin{tabular}{|c|c|c|c|c|c|c|}
\hline \multicolumn{2}{|c|}{ Model } & \multicolumn{2}{|c|}{ Unstandardized Coefficients } & \multirow{2}{*}{$\begin{array}{l}\text { Standardized } \\
\text { Coefficients } \\
\text { Beta }\end{array}$} & \multirow[t]{2}{*}{$\mathrm{t}$} & \multirow[t]{2}{*}{ Sig. } \\
\hline & & B & Std. Error & & & \\
\hline \multirow[t]{6}{*}{1} & (Constant) & .518 & .976 & & .530 & .602 \\
\hline & UP & -.087 & .042 & -.507 & -2.044 & .055 \\
\hline & LN_X1 & -.084 & .085 & -.219 & -.991 & .334 \\
\hline & LN_X2 & -.047 & .141 & -.066 & -.332 & .744 \\
\hline & LN_X4 & -.098 & .173 & -.120 & -.564 & .579 \\
\hline & LN_X5 & -.046 & .595 & -.018 & -.078 & .939 \\
\hline \multicolumn{7}{|c|}{ a. Dependent Variable: LN Y } \\
\hline
\end{tabular}

Sumber : Data sekunder, diolah 2019

Uji Multikonearitas

Multikonearitas terjadi jika terdapat hubungan linear yang sempurna atau hampir sempurna antara beberapa atau semua variabel independen dalam model regresi. Menurut Ghozali (2013) uji multikolinearitas bertujuan untuk menguji apakah model regresi ditemukan adanya korelasi antar variabel bebas (independen). Untuk menguji adanya multikolinearitas dapat dilakukan dengan menganalisis korelasi antar variabel dan perhitungan nilai tolerance serta variance infitaion factor (VIF).

Tabel 3.7 Hasil Uji Multikolinearitas

\begin{tabular}{|c|c|c|c|c|c|c|c|c|}
\hline \multirow{2}{*}{\multicolumn{2}{|c|}{ Model }} & \multicolumn{2}{|c|}{$\begin{array}{l}\text { Unstandardized } \\
\text { Coefficients }\end{array}$} & \multirow{2}{*}{$\begin{array}{l}\text { Standardized } \\
\text { Coefficients } \\
\text { Beta }\end{array}$} & \multirow[t]{2}{*}{$\mathrm{t}$} & \multirow[t]{2}{*}{ Sig. } & \multicolumn{2}{|c|}{$\begin{array}{l}\text { Collinearity } \\
\text { Statistics }\end{array}$} \\
\hline & & B & $\begin{array}{l}\text { Std. } \\
\text { Error }\end{array}$ & & & & Tolerance & VIF \\
\hline \multirow[t]{6}{*}{1} & (Constant) & 1.488 & .188 & & 7.905 & .000 & & \\
\hline & Profitabilitas & -.392 & .154 & -.313 & $-\overline{2.548}$ & .018 & .799 & 1.252 \\
\hline & Leverage & -.033 & .031 & -.137 & 1.056 & .302 & .710 & 1.408 \\
\hline & UP & -.044 & .007 & -.781 & $-\overline{6}-311$ & .000 & .785 & 1.274 \\
\hline & KA & -.003 & .002 & -.125 & $-\overline{1.043}$ & .307 & .836 & 1.196 \\
\hline & DKI & -.194 & .122 & -.192 & - & .124 & .826 & 1.210 \\
\hline
\end{tabular}

a. Dependent Variable: SR

Sumber : Data sekunder, diolah 2019 


\section{Uji Autokorelasi}

Uji autokorelasi adalah uji yang bertujuan untuk mengetahui ada atau tidak ada korelasi antar data berdasarkan urutan waktu (Ghozali, 2013). Untuk mengetahui ada atau tidak adanya autokorelasi dapat dilakukan melalui uji Durbin Watson (DW). Hasil uji autokorelasi ditunjukkan pada Tabel 3.8 sebagai berikut :

Tabel 3.8 Hasil Uji Autokorelasi sebelum menggunakan Cochrane Orcutt

\begin{tabular}{|c|c|c|c|c|c|c|c|c|c|c|}
\hline \multirow[t]{2}{*}{ Model } & \multirow[t]{2}{*}{$\mathrm{R}$} & \multirow{2}{*}{$\begin{array}{l}\mathrm{R} \\
\text { Square }\end{array}$} & \multirow{2}{*}{$\begin{array}{l}\text { Adjusted } \\
\text { R } \\
\text { Square }\end{array}$} & \multirow{2}{*}{$\begin{array}{l}\text { Std. } \\
\text { Error of } \\
\text { the } \\
\text { Estimate }\end{array}$} & \multicolumn{2}{|c|}{ Change Statistics } & \multirow[b]{2}{*}{ df1 } & \multirow[b]{2}{*}{$\mathrm{df} 2$} & \multirow[b]{2}{*}{$\begin{array}{l}\text { Sig. F } \\
\text { Change }\end{array}$} & \multirow{2}{*}{$\begin{array}{l}\text { Durbin- } \\
\text { Watson }\end{array}$} \\
\hline & & & & & $\begin{array}{l}\mathrm{R} \\
\text { Square } \\
\text { Change }\end{array}$ & $\begin{array}{l}\mathrm{F} \\
\text { Change }\end{array}$ & & & & \\
\hline 1 & $.844^{a}$ & .712 & .652 & .104927 & .712 & 11.843 & 5 & 24 & .000 & 1.659 \\
\hline
\end{tabular}

Sumber : Data sekunder, diolah 2019

Berdasarkan hasil uji Durbin Watson pada Tabel 3.8 dapat dilihat bahwa nilai DurbinWatson sebesar 1,659. Jadi 1,659 < 1,8326 sehingga dapat disimpulkan bahwa terjadi autokorelasi. Sehingga data tersebut tidak lolos uji autokorelasi. Salah satu cara agar data penelitian tidak terjadi autokorelasi adalah dengan Cochrane Orcutt.

Tabel 3.9 Hasil Uji Autokorelasi setelah menggunakan Cochrane Orcutt

\begin{tabular}{lllllll}
\hline Model & $\mathrm{R}$ & R Square & $\begin{array}{l}\text { Adjusted } \\
\text { Square }\end{array}$ & $\begin{array}{l}\text { R } \\
\text { Std. Error of the } \\
\text { Estimate }\end{array}$ & Durbin-Watson \\
\hline 1 & $.830^{\mathrm{a}}$ & .689 & .621 & .10431 & 1.895 \\
\hline
\end{tabular}

Sumber : Data sekunder, diolah 2019

Uji Hipotesis

Analisis Regresi Berganda

Dalam pengujian penelitian ini menggunakan analisis regresi linear berganda. Analisis regresi linear berganda dianggap tepat dalam pengujian ini karena analisis regresi tidak hanya menentukan besarnya pengaruh variabel independen terhadap dependen, tetapi juga menunjukkan arah dari pengaruh tersebut. Berdasarkan pada pengolahan data menggunakan SPSS maka diperoleh suatu model regresi berganda, dapat dilihat pada Table 3.10 sebagai berikut :

Tabel 3.10 Ringkasan Hasil Regresi Berganda

\begin{tabular}{|c|c|c|c|c|c|c|c|c|}
\hline \multirow{2}{*}{\multicolumn{2}{|c|}{ Model }} & \multicolumn{2}{|c|}{$\begin{array}{l}\text { Unstandardized } \\
\text { Coefficients }\end{array}$} & \multirow{2}{*}{$\begin{array}{l}\text { Standardized } \\
\text { Coefficients } \\
\text { Beta }\end{array}$} & \multirow[t]{2}{*}{$\mathrm{t}$} & \multirow[t]{2}{*}{ Sig. } & \multicolumn{2}{|c|}{ Collinearity Statistics } \\
\hline & & $\mathrm{B}$ & Std. Error & & & & Tolerance & VIF \\
\hline \multirow[t]{6}{*}{1} & (Constant) & 1.488 & .188 & & 7.905 & .000 & & \\
\hline & Profitabilitas & -.392 & .154 & -.313 & -2.548 & .018 & .799 & 1.252 \\
\hline & Leverage & -.033 & .031 & -.137 & -1.056 & .302 & .710 & 1.408 \\
\hline & UP & -.044 & .007 & -.781 & -6.311 & .000 & .785 & 1.274 \\
\hline & KA & -.003 & .002 & -.125 & -1.043 & .307 & .836 & 1.196 \\
\hline & DKI & -.194 & .122 & -.192 & -1.595 & .124 & .826 & 1.210 \\
\hline
\end{tabular}

Sumber : Data sekunder, diolah 2019

Berdasarkan Tabel di atas maka persamaan regresi yang diperoleh sebagai berikut : 


$$
\mathrm{SR}=1,488-0,392\left(\mathrm{X}_{1}\right)-0,033\left(\mathrm{X}_{2}\right)-0,044\left(\mathrm{X}_{3}\right)-0,003\left(\mathrm{X}_{4}\right)-0,194\left(\mathrm{X}_{5}\right)
$$

Koefisien Determinasi $\left(\mathrm{R}^{2}\right)$

Menurut Ghozali (2013) koefisien determinasi pada intinya mengukur seberapa jauh kemampuan sebuah model dalam menerangkan variasi variabel dependen. Nilai koefisien determinasi adalah antara 0 dan 1 . Nilai $R^{2}$ yang kecil berarti kemampuan variabel-variabel independen dalam mnjelaskan variasi variabel dependnen sangat terbatas. Nilai yang mendekati 1 berarti variabel-variabel independen sudah dapat memberi semua informasi yang dibutuhkan untuk memprediksi variabel dependen. Hasil pengujian dapat dilihat pada Tabel 3.11 sebagai berikut :

Tabel 3.11 Hasil Koefisien Determinasi (R2)

\begin{tabular}{lllllll}
\hline Model & $\mathrm{R}$ & $\mathrm{R}$ Square & $\begin{array}{l}\text { Adjusted } \\
\text { Square }\end{array}$ & $\mathrm{R}$ & $\begin{array}{l}\text { Std. Error of the } \\
\text { Estimate }\end{array}$ & Durbin-Watson \\
\hline 1 & $.830^{\mathrm{a}}$ & .689 & .621 & .10431 & 1.895 \\
\hline
\end{tabular}

Sumber : Data sekunder, diolah 2019

Uji Signifikansi Simultan/Uji F

Uji F digunakan untuk mengetahui apakah suatu model dalam penelitian ini layak dan dapat digunakan untuk memprediksi variabel dependen yaitu pengungkapan sustainability report dengan melakukan uji kelayakan model (fit) dengan menggunakan analisis uji F (Ghozali, 2013). Dikatakan model regresi layak (fit) jika nilai signifikan <0,05. Hasil dari uji $\mathbf{F}$ ditunjukkan pada Tabel 3.12 sebagai berikut :

Tabel 3.12 Hasil Uji F

\begin{tabular}{lllllll}
\hline Model & & Sum of Squares & df & Mean Square & F & Sig. \\
\hline 1 & Regression & .652 & 5 & .130 & 11.843 & $.000^{a}$ \\
& Residual & .264 & 24 & .011 & & \\
& Total & .916 & 29 & & & \\
\hline
\end{tabular}

Sumber : Data sekunder, diolah 2019

Uji t

Menurut Ghozali (2013) uji statistik t pada dasarnya menunjukkan seberapa jauh pengaruh satu variabel independen secara individual dalam menerangkan variabel dependen. Pengujian dilakukan dengan menggunakan signifikan level 0,05 $(\alpha=5 \%)$.Hasil uji statistik t dapat dilihat pada tabel di bawah ini :

Tabel $3.13 \mathrm{Uji}$ t

\begin{tabular}{|c|c|c|c|c|c|c|c|c|}
\hline \multirow{2}{*}{\multicolumn{2}{|c|}{ Model }} & \multicolumn{2}{|c|}{$\begin{array}{l}\text { Unstandardized } \\
\text { Coefficients }\end{array}$} & \multirow{2}{*}{$\begin{array}{l}\text { Standardized } \\
\text { Coefficients } \\
\text { Beta }\end{array}$} & \multirow[t]{2}{*}{$\mathrm{t}$} & \multirow[t]{2}{*}{ Sig. } & \multicolumn{2}{|c|}{$\begin{array}{l}\text { Collinearity } \\
\text { Statistics }\end{array}$} \\
\hline & & $\mathrm{B}$ & Std. Error & & & & Tolerance & VIF \\
\hline \multirow[t]{6}{*}{1} & (Constant) & 1.488 & .188 & & 7.905 & .000 & & \\
\hline & Profitabilitas & -.392 & .154 & -.313 & -2.548 & .018 & .799 & 1.252 \\
\hline & Leverage & -.033 & .031 & -.137 & -1.056 & .302 & .710 & 1.408 \\
\hline & UP & -.044 & .007 & -.781 & -6.311 & .000 & .785 & 1.274 \\
\hline & $\mathrm{KA}$ & -.003 & .002 & -.125 & -1.043 & .307 & .836 & 1.196 \\
\hline & DKI & -.194 & .122 & -.192 & -1.595 & .124 & .826 & 1.210 \\
\hline
\end{tabular}

Sumber : Data sekunder, diolah 2019 
Berdasarkan dari uji t pada Tabel 3.13 dapat diketahui bahwa profitabilitas memiliki signifikan sebesar 0,018. Tingkat signifikan tersebut lebih kecil dari taraf signifikan $\alpha=0,05$. Hal ini menunjukkan bahwa terdapat pengaruh yang signifikan antara profitabilitas terhadap pengungkapan sustainability report.

Profitabilitas merupakan kemampuan perusahaan untuk menghasilkan laba dalam upaya meningkatkan nilai pemegang saham. Hal ini sesuai dengan teori stakeholder yang menyatakan bahwa konsep tanggung jawab sosial perusahaan dimana kelangsungan hidup perusahaan dipengaruhi oleh para stakeholder. Jika tingkat profitabilitas semakin tinggi maka pengungkapan sustainability report juga tinggi, jika tingkat profitabilitas perusahaan semakin rendah maka pengungkapan sustainability report juga semakin rendah. Sebagai contoh perusahaan Multi Bintang Indonesia Tbk pada tahun 2017 mempunyai tingkat profitabilitas sebesar 0,53, dapat mengungkapkan sustainability report sebesar 0,20 dan perusahaan Charoen Pokphand Indonesia Tbk pada tahun tahun 2017 mempunyai tingkat profitabilitas sebesar 0,10 dapat mengungkapkan sustainability report sebesar 0,29. Sebaliknya perusahaan Semen Indonesia (Persero) Tbk pada tahun 2017 mempunyai tingkat profitabilitas rendah sebesar 0,04, pengungkapan sustainability report juga rendah dengan nilai 0,09 .

Hasil penelitian ini sesuai dengan penelitian yang dilakukan oleh Nasir dkk., (2014), Sari dan Marsono (2013) dan Jannah (2016) karena profitabilitas yang tinggi dapat mempengaruhi pengungkapan sustainability report, dimana hal ini akan mempengaruhi tingkat kepercayaan stakeholder bahwasanya perusahaan telah melakukan pertanggung jawaban sosial kepada masyarakat sehingga pembangunan keberlanjutan perusahaan dapat berlangsung. Berbeda dengan penelitian Saputro dkk., (2013) yang menyatakan bahwa profitabilitas tidak signifikan berpengaruh terhadap pengungkapan sustainability report karena tidak adanya manfaat secara langsung keuntungan dalam bentuk profitabilitas yang lebih didapat ketika perusahaan mengungkapkan sustainability report.

Berdasarkan dari uji t pada Tabel 3.13 dapat diketahui bahwa leverage memiliki signifikan sebesar 0,302. Tingkat signifikan tersebut lebih besar dari taraf signifikan $\alpha=0,05$. Hal ini menunjukkan bahwa tidak terdapat pengaruh yang signifikan antara leverage terhadap pengungkapan sustainability report.

Tidak adanya pengaruh leverage terhadap pengungkapan sustainability report disebabkan karena semakin tinggi tingkat leverage, maka perusahaan akan berusaha melaporkan profitabilitas agar tetap tinggi. Perusahaan yang mempunyai tingkat leverage yang tinggi berarti sangat tergantung pada pinjaman luar untuk membiayai asetnya. Sedangkan perusahaan yang mempunyai tingkat leverage rendah lebih banyak membiayai asetnya dengan modal sendiri. Hasil penelitian ini sama dengan Sari dan Marsono (2013), Rifandi (2017) dan Saputro dkk., (2013) yang dapat diartikan bahwa perusahaan yang memiliki tingkat leverage yang tinggi akan mencerminkan perusahaan tersebut juga memiliki modal kerja tersedia yang cukup, sehingga perusahaan akan cenderung mengungkapkan informasi seperlunya saja. Sebagai contoh perusahaan Wijaya Karya beton pada tahun 2017 memiliki tingkat leverage tertinggi sebesar 2,12 dan hanya mengungkapkan sustainability report sebesar 0,10 sedangkan perusahaan Semen Indonesia (Persero) Tbk pada tahun 2015 hanya memiliki tingkat leverage sebesar 0,39 dapat mengungkapkan sustainability report sebesar 0,35 , hal ini menjadi salah satu faktor ditolaknya hipotesis kedua. Besar kecilnya tingkat leverage tidak mempengaruhi perusahaan dalam mengungkapkan sustainability report karena untuk mendapatkan laba yang tinggi, perusahaan dapat melakukan pengurangan biaya-biaya untuk dapat mengungkapkan sustainability report. Berbeda dengan penelitian Nasir (2014) dan Aniktia dan Khafid (2015) yang menyatakan bahwa leverage berpengaruh signifikan terhadap pengungkapan sustainability report.

Berdasarkan dari uji t pada Tabel 3.13 dapat diketahui bahwa ukuran perusahaan memiliki signifikan sebesar 0,000 . Tingkat signifikan tersebut lebih kecil dari taraf signifikan $\alpha=0,05$. Hal ini menunjukkan bahwa terdapat pengaruh yang signifikan antara ukuran perusahaan terhadap pengungkapan sustainability report.

Hasil penelitian ini konsisten dengan hasil penelitian sebelumnya yang telah dilakukan oleh Suryono dan Prastiwi (2011), Idah (2013), Rifandi (2017) dan Luthfia (2012), ukuran 
perusahaan dengan sustainability report berbanding searah. Perusahaan yang memiliki ukuran perusahaan besar cenderung lebih di sorot oleh para masyarakat maupun stakeholder, maka mereka akan melakukan pengungkapan yang lebih banyak dibandingkan dengan perusahaan yang ukurannya kecil dengan tujuan untuk lebih meyakinkan para stakeholder. Semakin besar ukuran perusahaan, maka akan semakin memperoleh perhatian dari stakeholder. Maka, perusahaan berusaha untuk memperoleh legitimasi dari para stakeholder salah satunya dengan cara mengungkapkan informasi secara lengkap, baik informasi yang sifatnya wajib ataupun sukarela. Sebagai contoh perusahaan Astra International Tbk pada tahun 2017 memiliki nilai ukuran perusahaan sebesar 26,41 dan dapat mengungkapkan sustainability report sebesar 0,018 dan perusahaan Indocement Tunggal Prakarsa Tbk pada tahun 2015 memiliki nilai ukuran perusahaan sebesar 24,04 dan dapat mengungkapkan sustainability report sebesar 0,43.

Berdasarkan dari uji t pada Tabel 3.13 dapat diketahui bahwa komite audit memiliki signifikan sebesar 0,307. Tingkat signifikan tersebut lebih besar dari taraf signifikan $\alpha=0,05$. Hal ini menunjukkan bahwa tidak terdapat pengaruh yang signifikan antara komite audit terhadap pengungkapan sustainability report.

Hal ini sesuai dengan penelitian yang dilakukan sebelumnya oleh Dilling (2009) dan Ratnasari (2011). Hasil ini dapat disebabkan karena rapat-rapat yang diselenggarakan oleh komite audit kurang efektif, dimana anggota komite audit lebih mengedepankan kepentingan pribadi maupun kelompok dari pada kepentingan dari perusahaan. Kurangnya kompetensi dari komite audit sehingga tidak mampu melakukan tugasnya dengan baik (Waryanto dalam Ratnasari, 2011). Rapat komite audit lebih melakukan tugasnya dalam hal pengawasan laporan keauangan daripada pengungkapan informasi sosial dan lingkungan, sehingga rapat komite audit tidak berpengaruh terhadap pengungkapan sustainability report. Tugas komite audit disini menganalisis kebijakan akuntansi yang diterapkan oleh perusahaan, menilai pengendalian internal, menganalisis sistem pelaporan eksternal dan kepatuhan terhadap peraturan. Komite audit yang diproksikan dengan jumlah rapat anggota komite audit menunjukkan bahwa komite audit tidak berpengaruh terhadap pengungkapan sustainability report. Sejalan dengan hasil penelitian dari Mulia dalam Anugerah (2011) yang mengungkapkan bahwa ditolaknya hipotesis ini dapat disebabkan oleh kurangnya kompetensi anggota komite audit yang independen, sehingga meskipun diharapkan dapat memangku kepentingan perusahaan secara obyektif, namun tidak dapat melaksanakan fungsinya secara optimal. Kurangnya kompetensi anggota komite audit bisa berpengaruh terhadap turunnya luas pengungkapan laporan yang sifatnya sukarela, misalnya pengungkapan sustainability report.

Berdasarkan dari uji t pada tabel 3.13 dapat diketahui bahwa dewan komisaris independen memiliki signifikan sebesar 0,124. Tingkat signifikan tersebut lebih besar dari taraf signifikan $\alpha=$ 0,05 . Hal ini menunjukkan bahwa tidak terdapat pengaruh yang signifikan antara dewan komisaris independen terhadap pengungkapan sustainability report.

Tidak berpengaruhnya dewan komisaris independen terhadap pengungkapan sustainability report dimungkinkan karena beberapa alasan. Alasan pertama yaitu dewan komisaris independen belum melaksanakan tugas dan fungsinya secara maksimal. Menurut Restuningdiah (2010) meskipun terdapat dewan komisaris independen, namun apabila dewan komisaris independen tidak memiliki waktu untuk perusahaan karena kesibukannya yang lain, maka keberadaan dewan komisaris independen tidak akan efektif. Alasan kedua adalah faktor dari dalam individu anggota komisaris independen. Menurut Stranberg dalam Restuningdiah (2010) kompetensi dewan komisaris memegang peranan penting dalam pengambilan keputusan, sehingga bukan hanya komposisi dewan komisaris independen yang dipertimbangkan, namun juga kemampuan (skill), pengetahuan, latar belakang dan kompetensi sehingga dapat meningkatkan kualitas pengambilan keputusan pada tingkat dewan komisaris. Alasan ketiga adalah karena independensi komisaris independen. Menurut Putri (2013), tidak semua anggota dewan komisaris independen dapat menunjukkan independensinya sehingga fungsi pengawasan tidak berjalan dengan baik dan berdampak pada kurangnya dorongan terhadap manajemen untuk melakukan pengungkapan sosial. Alasan keempat dimungkinkan dari segi pandangan anggota dewan komisaris independen. Menurut Putri (2013) dewan komisaris independen belum menganggap perlu mengenai ada atau tidaknya pengungkapan CSR dalam sustainability report. 


\section{KESIMPULAN}

Berdasarkan hasil pengujian dan analisa yang telah dijelaskan, maka dapat disimpulkan Profitabilitas berpengaruh terhadap terhadap pengungkapan sustainability report. Hal ini menunjukkan bahwa besar kecilnya profitabilitas suatu perusahaan akan berpengaruh secara signifikan terhadap terhadap pengungkapan sustainability report. Leverage tidak berpengaruh terhadap terhadap pengungkapan sustainability report. Hal ini menunjukkan bahwa besar kecilnya leverage suatu perusahaan tidak berpengaruh secara signifikan terhadap terhadap pengungkapan sustainability report. Ukuran perusahaan berpengaruh terhadap terhadap pengungkapan sustainability report. Hal ini menunjukkan bahwa besar kecilnya ukuran perusahaan suatu perusahaan akan berpengaruh secara signifikan terhadap terhadap pengungkapan sustainability report. Komite Audit tidak berpengaruh terhadap terhadap pengungkapan sustainability report. Hal ini menunjukkan bahwa besar kecilnya komite audit suatu perusahaan tidak berpengaruh secara signifikan terhadap terhadap pengungkapan sustainability report. Dewan Komisaris Independen tidak berpengaruh terhadap terhadap pengungkapan sustainability report. Hal ini menunjukkan bahwa besar kecilnya Dewan Komisaris Independen suatu perusahaan tidak berpengaruh secara signifikan terhadap terhadap pengungkapan sustainability report.

Berdasarkan pembahasan dan kesimpulan penelitian maka dapat diberikan beberapa saran, memperhatikan kriteria pemilihan sampel, perusahaan yang digunakan tidak hanya perusahaan yang terdaftar di BEI, misalnya dapat menggunakan perusahaan BUMN yang sudah menerbitkan sustainability report. Dapat menggunakan pedoman terbaru yang sudah disesuaikan dengan kondisi perusahaan di Indonesia selain GRI 2013 untuk mengukur pengungkapan sustainability report agar hasilnya lebih sesuai dengan kondisi perusahaan.

\section{LAMPIRAN}

Lampiran 1

Perusahaan Manufaktur yang Terdaftar di BEI Mulai dari Tahun 2015-2017

\begin{tabular}{ccc}
\hline NO & KODE PERUSAHAAN & NAMA PERUSAHAAN \\
\hline 1. & SMBR & Semen Baturaja Persero Tbk \\
2. & AMFG & Asahimas Flat Glass Tbk \\
3. & ARNA & Arwana Citra Mulia Tbk \\
4. & IKAI & Inti Keramik Alam Asri Industri Tbk \\
5. & KIAS & Keramika Indonesia Assosiasi Tbk \\
6. & MLIA & Mulia Industrindo Tbk \\
7. & TOTO & Surya Toto Indonesia Tbk \\
8. & ALKA & Alaska Industrindo Tbk \\
9. & ALMI & Alumindo Light Metal Industry Tbk \\
10. & BAJA & Saranacentral Bajatama Tbk \\
11. & BTON & Beton Jaya Manunggal Tbk \\
12. & CTBN & Citra Turbindo Tbk \\
13. & GDST & Gunawan Dianjaya Steel Tbk \\
14. & INAI & Indal Aluminium Industry Tbk \\
15. & ISSP & Steel Pipe Industry of Indonesia Tbk \\
16. & JKSW & Jakarta Kyoei Steel Work LTD Tbk \\
17. & JPRS & Jaya Pari Steel Tbk \\
18. & KRAS & Krakatau Steel Tbk \\
19. & LION & Lion Metal Works Tbk \\
20. & LMSH & Lionmesh Prima Tbk \\
21. & NIKL & Pelat Timah Nusantara Tbk \\
22. & PICO & Pelangi Indah Canindo Tbk \\
23. & TBMS & Tembaga Mulia Semanan Tbk \\
24. & BRPT & Barito Pasific Tbk \\
\hline
\end{tabular}




\begin{tabular}{|c|c|c|}
\hline NO & KODE PERUSAHAAN & $\begin{array}{l}\text { NAMA PERUSAHAAN } \\
\end{array}$ \\
\hline 25. & BUDI & Budi Starch and Sweetener Tbk d.h Budi Acid Jaya Tbk \\
\hline 26. & DPNS & Duta Pertiwi Nusantara \\
\hline 27. & EKAD & Ekadharma International Tbk \\
\hline 28. & ETWA & Eterindo Wahanatama Tbk \\
\hline 29. & INCI & Intan Wijaya International Tbk \\
\hline 30 . & SOBI & Sorini Agro Asia Corporindo Tbk \\
\hline 31. & SRSN & Indo Acitama Tbk \\
\hline 32. & TPIA & Chandra Asri Petrochemical \\
\hline 33. & UNIC & Unggul Indah Cahaya Tbk \\
\hline 34. & $\mathrm{AKKU}$ & Alam Karya Unggul Tbk \\
\hline 35. & AKPI & Argha Karya Prima Industry Tbk \\
\hline 36. & APLI & Asiaplast Industries Tbk \\
\hline 37. & BRNA & Berlina Tbk \\
\hline 38. & FPNI & $\begin{array}{c}\text { Lotte Chemical Titan Tbk d.h Titan Kimia Nusantara Tbk d.h } \\
\text { Fatra Polindo Nusa Industri Tbk }\end{array}$ \\
\hline 39. & IGAR & Champion Pasific Indonesia Tbk d.h Kageo Igar Jaya Tbk \\
\hline 40 . & IMPC & Impack Pratama Industri Tbk \\
\hline 41. & IPOL & Indopoly Swakarsa Industry Tbk \\
\hline 42. & SIAP & Sekawan Intipratama Tbk \\
\hline 43. & SIMA & Siwani Makmur Tbk \\
\hline 44. & TALF & Tunas Alfin Tbk \\
\hline 45. & TRST & Trias Sentosa Tbk \\
\hline 46. & YPAS & Yana Prima Hasta Persada Tbk \\
\hline 47. & JPFA & Japfa Comfeed Indonesia Tbk \\
\hline 48. & MAIN & Malindo Feedmill Tbk \\
\hline 49. & SIPD & Siearad Produce Tbk \\
\hline 50 . & SULI & SLJ Global Tbk d.h Sumalindo Lestari Jaya Tbk \\
\hline 51. & TIRT & Tirta Mahakam Resources Tbk \\
\hline 52. & ALDO & Alkindo Naratama Tbk \\
\hline 53. & DAJK & Dwi Aneka Jaya Kemasindo Tbk \\
\hline 54. & FASW & Fajar Surya Wisesa Tbk \\
\hline 55. & INKP & Indah Kiat Pulp \& paper Tbk \\
\hline 56. & INRU & Toba Pulp Lestari Tbk \\
\hline 57. & KBRI & Kertas Basuki Rachmat Indonesia Tbk \\
\hline 58. & KDSI & Kedaung Setia Industrial Tbk \\
\hline 59. & SPMA & Suparma Tbk \\
\hline 60 . & AMIN & Ateliers Mecaniques D'Indonesie Tbk \\
\hline 61. & KRAH & Grand Kartech Tbk \\
\hline 62. & AUTO & Astra Auto Part Tbk \\
\hline 63. & BOLT & Garuda Metalindo Tbk \\
\hline 64. & BRAM & Indo Kordsa Tbk d.h Branta Mulia Tbk \\
\hline 65. & GDYR & Goodyear Indonesia Tbk \\
\hline 66. & GJTL & Gajah Tunggal Tbk \\
\hline 67. & IMAS & Indomobil Sukses International Tbk \\
\hline 68. & INDS & Indospring Tbk \\
\hline 69. & PRAS & Prima alloy steel Universal Tbk \\
\hline 70. & SMSM & Selamat Sempurna Tbk \\
\hline 71. & ADMG & Polychem Indonesia Tbk \\
\hline 72. & ARGO & Argo Pantes Tbk \\
\hline 73. & CNTX & Centex Tbk \\
\hline 74. & ERTX & Eratex Djaya Tbk \\
\hline 75. & ESTI & Ever Shine Textile Industry Tbk \\
\hline 76. & HDTX & Panasia Indo Resources Tbk d.h Panasia Indosyntec Tbk \\
\hline 77. & INDR & Indo Rama Synthetic Tbk \\
\hline 78. & MYTX & Apac Citra Centertex Tbk \\
\hline 79. & PBRX & Pan Brothers Tbk \\
\hline 80 . & POLY & Asia Pasific Fibers Tbk $d . h$ Polysindo Eka Persada Tbk \\
\hline 81. & RICY & Ricky Putra Globalindo Tbk \\
\hline 82. & STAR & Star Petrochem Tbk \\
\hline 83. & TFCO & Tifico Fiber Indonesia Tbk \\
\hline
\end{tabular}




\begin{tabular}{|c|c|c|}
\hline NO & KODE PERUSAHAAN & NAMA PERUSAHAAN \\
\hline 84. & SRIL & Sri Rejeki Isman Tbk \\
\hline 85. & SSTM & Sunson Textile Manufacturer Tbk \\
\hline 86. & TRIS & Trisula International Tbk \\
\hline 87. & UNIT & Nusantara Inti Corpora Tbk \\
\hline 88. & BATA & Sepatu Bata Tbk \\
\hline 89. & BIMA & Primarindo Asia Infrastructure Tbk \\
\hline 90 . & IKBI & Sumi Indo Kabel Tbk \\
\hline 91. & JECC & Jembo Cable Company Tbk \\
\hline 92. & KBLI & KMI Wire and Cable Tbk \\
\hline 93. & KBLM & Kabelindo Murni Tbk \\
\hline 94. & SCCO & Supreme Cable Manufacturing and Commerce Tbk \\
\hline 95. & VOKS & Voksel Electric Tbk \\
\hline 96. & PTSN & Sat Nusa Persada Tbk \\
\hline 97. & AISA & Tiga Pilar Sejahtera Food Tbk \\
\hline 98. & ALTO & Tri Banyan Tirta Tbk \\
\hline 99. & CEKA & Cahaya Kalbar Tbk \\
\hline 100. & DLTA & Delta Djakarta Tbk \\
\hline 101. & ICBP & Indofood CBP Sukses Makmur Tbk \\
\hline 102. & INDF & Indofood Sukses Makmur Tbk \\
\hline 103. & MYOR & Mayora Indah Tbk \\
\hline 104. & PSDN & Prashida Aneka Niaga Tbk \\
\hline 105. & ROTI & Nippon Indosari Corporindo Tbk \\
\hline 106. & SKBM & Sekar Bumi Tbk \\
\hline 107. & SKLT & Sekar Laut Tbk \\
\hline 108. & STTP & Siantar Top Tbk \\
\hline 109. & ULTJ & Ultrajaya Milk Industry and Trading Company Tbk \\
\hline 110. & GGRM & Gudang Garam Tbk \\
\hline 111. & HMSP & Hanjaya Mandala Sampoerna Tbk \\
\hline 112. & RMBA & Bentoel International Investama Tbk \\
\hline 113. & WIIM & Wismilak Inti Makmur Tbk \\
\hline 114. & DVLA & Darya Varia Laboratoria Tbk \\
\hline 115. & INAF & Indofarma Tbk \\
\hline 116. & KAEF & Kimia Farma Tbk \\
\hline 117. & MERK & Merck Tbk \\
\hline 118. & PYFA & Pyridam Farma Tbk \\
\hline 119. & SCPI & Schering Plough Indonesia Tbk \\
\hline 120. & SIDO & Industri Jamu dan Farmasi Sido Muncul Tbk \\
\hline 121. & SQBI \& SQBB & Taisho Pharmaceutical Indonesia Tbk \\
\hline 122. & TSPC & Tempo Scan Pasific Tbk \\
\hline 123. & ADES & $\begin{array}{c}\text { Akasha Wira International Tbk d.h Ades Waters Indonesia } \\
\text { Tbk }\end{array}$ \\
\hline 124. & KINO & Kino Indonesia Tbk \\
\hline 125. & MBTO & Martina Berto Tbk \\
\hline 126. & MRAT & Mustika Ratu Tbk \\
\hline 127. & TCID & Mandom Indonesia Tbk \\
\hline 128. & CINT & Chitose Internasional Tbk \\
\hline 129. & KICI & Kedaung Indag Can Tbk \\
\hline 130. & LMPI & Langgeng Makmur Industry Tbk \\
\hline 131. & SMGR & Semen Indonesia (Persero) Tbk \\
\hline 132. & WTON & Wijaya Karya Beton \\
\hline 133. & MLBI & Multi Bintang Indonesia Tbk \\
\hline 134. & TKIM & Pabrik Kertas Tjiwi Kimia Tbk \\
\hline 135. & CPIN & Charoen Pokphand Indonesia Tbk \\
\hline 136. & ASII & Astra International Tbk \\
\hline 137. & INTP & Indocement Tunggal Prakarsa Tbk \\
\hline 138. & UNVR & Unilever Indonesia Tbk \\
\hline 139. & SMCB & Holcim Indonesia Tbk \\
\hline 140 . & GMFI & PT Garuda Maintenance Facility Aero Asia Tbk \\
\hline 141. & LPIN & Multi Prima Sejahtera Tbk $d . h$ Lippo Enterprises Tbk \\
\hline 142. & MASA & Multistrada Arah Sarana Tbk \\
\hline
\end{tabular}


Lampiran 2

Daftar Sampel Penelitian

\begin{tabular}{ccc}
\hline No & Kode Perusahaan & Nama Perusahaan \\
\hline 1. & SMGR & Semen Indonesia (Persero) Tbk \\
2. & WTON & Wijaya Karya Beton \\
3. & MLBI & Multi Bintang Indonesia Tbk \\
4. & TKIM & Pabrik Kertas Tjiwi Kimia Tbk \\
5. & CPIN & Charoen Pokphand Indonesia Tbk \\
6. & ASII & Astra International Tbk \\
7. & INTP & Indocement Tunggal Prakarsa Tbk \\
8. & UNVR & Unilever Indonesia Tbk \\
9. & SMCB & Holcim Indonesia Tbk \\
10. & GMFI & PT Garuda Maintenance Facility Aero Asia Tbk \\
\hline
\end{tabular}

Lampiran 3

Perhitungan Profitabilitas Rp

\begin{tabular}{|c|c|c|c|c|c|c|c|}
\hline No & Tahun & Kode & \multicolumn{2}{|c|}{ Laba Bersih } & \multicolumn{2}{|c|}{ Total Aset } & Roa \\
\hline & 2015 & & $\mathrm{Rp}$ & $4,525,441,038$ & $\mathrm{Rp}$ & $38,153,118,932$ & 0.118612611 \\
\hline \multirow[t]{3}{*}{1} & 2016 & SMGR & $\mathrm{Rp}$ & $4,535,036,823$ & $\mathrm{Rp}$ & $44,226,895,982$ & 0.102540247 \\
\hline & 2017 & & $\mathrm{Rp}$ & $2,043,025,914$ & Rp & $48,963,502,966$ & 0.041725485 \\
\hline & 2015 & & $\mathrm{Rp}$ & $703,005,054$ & $\mathrm{Rp}$ & $19,602,406,034$ & 0.035863202 \\
\hline \multirow[t]{3}{*}{2} & 2016 & WTON & $\mathrm{Rp}$ & $1,147,144,922$ & $\mathrm{Rp}$ & $31,096,539,490$ & 0.036889794 \\
\hline & 2017 & & $\mathrm{Rp}$ & $1,356,115,489$ & Rp & $45,683,774,302$ & 0.029684839 \\
\hline & 2015 & & $\mathrm{Rp}$ & $496,909,000$ & $\mathrm{Rp}$ & $2,100,853,000$ & 0.236527258 \\
\hline \multirow[t]{3}{*}{3} & 2016 & MLBI & $\mathrm{Rp}$ & $982,129,000$ & $\mathrm{Rp}$ & $2,275,038,000$ & 0.431697844 \\
\hline & 2017 & & $\mathrm{Rp}$ & $1,322,067,000$ & Rp & $2,510,078,000$ & 0.526703553 \\
\hline & 2015 & & $\mathrm{Rp}$ & $1,832,598,000$ & Rp & $24,684,915,000$ & 0.074239591 \\
\hline \multirow[t]{3}{*}{4} & 2016 & CPIN & $\mathrm{Rp}$ & $2,225,402,000$ & $\mathrm{Rp}$ & $24,204,994,000$ & 0.091939787 \\
\hline & 2017 & & $\mathrm{Rp}$ & $2,496,787,000$ & $\mathrm{Rp}$ & $24,522,593,000$ & 0.101815783 \\
\hline & 2015 & & $\mathrm{Rp}$ & $15,613,000,000$ & $\mathrm{Rp}$ & $245,435,000,000$ & 0.063613584 \\
\hline \multirow[t]{3}{*}{5} & 2016 & ASII & $\mathrm{Rp}$ & $18,302,000,000$ & $\mathrm{Rp}$ & $261,885,000,000$ & 0.069885637 \\
\hline & 2017 & & $\mathrm{Rp}$ & $23,165,000,000$ & $\mathrm{Rp}$ & $295,646,000,000$ & 0.078353842 \\
\hline & 2015 & & $\mathrm{Rp}$ & $4,356,661,000$ & $\mathrm{Rp}$ & $27,638,360,000$ & 0.157630952 \\
\hline \multirow[t]{3}{*}{6} & 2016 & INTP & $\mathrm{Rp}$ & $3,870,319,000$ & $\mathrm{Rp}$ & $30,150,580,000$ & 0.12836632 \\
\hline & 2017 & & $\mathrm{Rp}$ & $1,859,818,000$ & $\mathrm{Rp}$ & $28,863,676,000$ & 0.064434551 \\
\hline & 2015 & & $\mathrm{Rp}$ & $5,851,805,000$ & $\mathrm{Rp}$ & $15,729,945,000$ & 0.372016876 \\
\hline \multirow[t]{3}{*}{7} & 2016 & UNVR & $\mathrm{Rp}$ & $6,390,672,000$ & $\mathrm{Rp}$ & $16,745,695,000$ & 0.381630742 \\
\hline & 2017 & & $\mathrm{Rp}$ & $7,004,562,000$ & $\mathrm{Rp}$ & $18,906,413,000$ & 0.370486036 \\
\hline & 2015 & & $\mathrm{Rp}$ & $175,127,000$ & $\mathrm{Rp}$ & $17,321,565,000$ & 0.010110345 \\
\hline \multirow[t]{2}{*}{8} & 2016 & SMCB & $\mathrm{Rp}$ & $284,584,000$ & $\mathrm{Rp}$ & $19,763,133,000$ & 0.014399741 \\
\hline & 2017 & & $\mathrm{Rp}$ & $758,045,000$ & $\mathrm{Rp}$ & $19,626,403,000$ & 0.038623736 \\
\hline
\end{tabular}

Lampiran 4

Perhitungan Profitabilitas USD

\begin{tabular}{rlrrrrrl}
\hline \multicolumn{2}{c}{ No } & Tahun & Kode & \multicolumn{2}{l}{ Laba Bersih } & \multicolumn{2}{l}{ Total Aset } \\
\hline \multirow{2}{*}{1} & 2015 & & $\$$ & 1,452 & $\$$ & $2,683,873$ & 0.000541009 \\
& 2016 & TKIM & $\$$ & 7,653 & $\$$ & $2,491,282$ & 0.003071912 \\
& 2017 & & $\$$ & 27,310 & $\$$ & $2,580,875$ & 0.010581683 \\
& 2015 & & $\$$ & $36,184,965.00$ & $\$$ & $312,994,597.00$ & 0.115608913 \\
2 & 2016 & \multirow{2}{*}{ GMFI } & $\$$ & $57,742,213.00$ & $\$$ & $442,589,107.00$ & 0.130464605 \\
& 2017 & & $\$$ & $50,946,349.00$ & $\$$ & $539,150,882.00$ & 0.094493676 \\
\hline
\end{tabular}


Lampiran 5

Perhitungan Leverage Rp

\begin{tabular}{|c|c|c|c|c|c|c|c|}
\hline No & Tahun & Kode & & tal Modal & & tal Hutang & Leverage \\
\hline & 2015 & & Rp & $27,440,798,401$ & $\mathrm{Rp}$ & $10,712,320,531$ & 0.390379331 \\
\hline 1 & 2016 & SMGR & $\mathrm{Rp}$ & $30,574,391,457$ & $\mathrm{Rp}$ & $13,652,504,525$ & 0.446533974 \\
\hline & 2017 & & $\mathrm{Rp}$ & $30,439,052,302$ & $\mathrm{Rp}$ & $18,524,450,664$ & 0.608575145 \\
\hline & 2015 & & Rp & $5,438,101,365$ & $\mathrm{Rp}$ & $14,164,304,669$ & 2.604641532 \\
\hline 2 & 2016 & WTON & $\mathrm{Rp}$ & $12,498,715,304$ & Rp & $18,597,824,186$ & 1.487978863 \\
\hline & 2017 & & Rp & $14,631,824,613$ & $\mathrm{Rp}$ & $31,051,949,689$ & 2.122219922 \\
\hline & 2015 & & $\mathrm{Rp}$ & $766,480,000$ & $\mathrm{Rp}$ & $1,334,373,000$ & 1.740910396 \\
\hline 3 & 2016 & MLBI & $\mathrm{Rp}$ & $820,640,000$ & $\mathrm{Rp}$ & $1,454,398,000$ & 1.77227286 \\
\hline & 2017 & & Rp & $1,064,905,000$ & $\mathrm{Rp}$ & $1,445,173,000$ & 1.357091008 \\
\hline & 2015 & & $\mathrm{Rp}$ & $12,561,427,000$ & $\mathrm{Rp}$ & $12,123,488,000$ & 0.9651 \\
\hline 4 & 2016 & CPIN & $\mathrm{Rp}$ & $14,157,243,000$ & $\mathrm{Rp}$ & $10,047,751,000$ & 0.7097 \\
\hline & 2017 & & $\mathrm{Rp}$ & $15,702,825,000$ & $\mathrm{Rp}$ & $8,819,768,000$ & 0.5617 \\
\hline & 2015 & & Rp & $126,533,000,000$ & Rp & $118,902,000,000$ & 0.9397 \\
\hline 5 & 2016 & ASII & $\mathrm{Rp}$ & $139,906,000,000$ & $\mathrm{Rp}$ & $121,949,000,000$ & 0.8716 \\
\hline & 2017 & & $\mathrm{Rp}$ & $156,329,000,000$ & $\mathrm{Rp}$ & $139,317,000,000$ & 0.8912 \\
\hline & 2015 & & Rp & $23,865,950,000$ & $\mathrm{Rp}$ & $3,772,410,000$ & 0.1581 \\
\hline 6 & 2016 & INTP & $\mathrm{Rp}$ & $26,138,703,000$ & $\mathrm{Rp}$ & $4,011,877,000$ & 0.1535 \\
\hline & 2017 & & $\mathrm{Rp}$ & $24,556,507,000$ & $\mathrm{Rp}$ & $4,307,169,000$ & 0.1754 \\
\hline & 2015 & & $\mathrm{Rp}$ & $4,827,360,000$ & $\mathrm{Rp}$ & $10,902,585,000$ & 2.2585 \\
\hline 7 & 2016 & UNVR & $\mathrm{Rp}$ & $4,704,258,000$ & $\mathrm{Rp}$ & $12,041,437,000$ & 2.5597 \\
\hline & 2017 & & Rp & $5,173,388,000$ & $\mathrm{Rp}$ & $13,733,025,000$ & 2.6546 \\
\hline & 2015 & & $\mathrm{Rp}$ & $8,449,857,000$ & $\mathrm{Rp}$ & $8,871,708,000$ & 1.0499 \\
\hline 8 & 2016 & SMCB & $\mathrm{Rp}$ & $8,060,595,000$ & $\mathrm{Rp}$ & $11,702,538,000$ & 1.4518 \\
\hline & 2017 & & $\mathrm{Rp}$ & $7,196,951,000$ & $\mathrm{Rp}$ & $12,429,452,000$ & 1.7270 \\
\hline
\end{tabular}

Lampiran 6

Perhitungan Leverage USD

\begin{tabular}{rlllrlrr}
\hline No & Tahun & Kode & \multicolumn{2}{l}{ Total Modal } & \multicolumn{2}{c}{ Total Hutang } & Leverage \\
\hline \multirow{2}{*}{1} & 2015 & & $\$$ & 956,119 & $\$$ & $1,727,754$ & 1.8070 \\
& 2016 & TKIM & $\$$ & 937,078 & $\$$ & $1,554,204$ & 1.6586 \\
& 2017 & & $\$$ & 996,740 & $\$$ & $1,584,135$ & 1.5893 \\
\multirow{2}{*}{2} & 2015 & & $\$$ & $122,791,864.00$ & $\$$ & $196,202,733.00$ & 1.5978 \\
& 2016 & GMFI & $\$$ & $172,554,748.00$ & $\$$ & $270,034,359.00$ & 1.5649 \\
& 2017 & & $\$$ & $305,788,575.00$ & $\$$ & $233,362,307.00$ & 0.7631 \\
\hline
\end{tabular}

Lampiran 7

Perhitungan Ukuran Perusahaan Rp

\begin{tabular}{|c|c|c|c|c|}
\hline No & Tahun & Kode & Total Aset & Ukuran Perusahaan \\
\hline \multirow{3}{*}{1} & 2015 & \multirow{3}{*}{ SMGR } & $\operatorname{Rp} 38,153,118,932$ & 24.36487335 \\
\hline & 2016 & & $\operatorname{Rp} 44,226,895,982$ & 24.51259895 \\
\hline & 2017 & & $\operatorname{Rp} 48,963,502,966$ & 24.61434102 \\
\hline \multirow{3}{*}{2} & 2015 & \multirow{3}{*}{ WTON } & $\operatorname{Rp} 19,602,406,034$ & 23.69891815 \\
\hline & 2016 & & Rp 31,096,539,490 & 24.16036238 \\
\hline & 2017 & & $\operatorname{Rp} 45,683,774,302$ & 24.54500902 \\
\hline \multirow{3}{*}{3} & 2015 & \multirow{3}{*}{ MLBI } & $\operatorname{Rp} 2,100,853,000$ & 21.46560929 \\
\hline & 2016 & & $\operatorname{Rp} 2,275,038,000$ & 21.54526259 \\
\hline & 2017 & & $\operatorname{Rp} 2,510,078,000$ & 21.64357967 \\
\hline \multirow{3}{*}{4} & 2015 & \multirow{3}{*}{ CPIN } & $\operatorname{Rp} 24,684,915,000$ & 23.92945817 \\
\hline & 2016 & & Rp 24,204,994,000 & 23.90982481 \\
\hline & 2017 & & $\operatorname{Rp} 24,522,593,000$ & 23.92286069 \\
\hline \multirow{3}{*}{5} & 2015 & \multirow{3}{*}{ ASII } & $\operatorname{Rp} 245,435,000,000$ & 26.22629798 \\
\hline & 2016 & & Rp $261,885,000,000$ & 26.29117131 \\
\hline & 2017 & & Rp 295,646,000,000 & 26.41242863 \\
\hline \multirow{3}{*}{6} & 2015 & \multirow{3}{*}{ INTP } & Rp 27,638,360,000 & 24.0424705 \\
\hline & 2016 & & $\operatorname{Rp} 30,150,580,000$ & 24.12947 \\
\hline & 2017 & & $\operatorname{Rp} 28,863,676,000$ & 24.08584976 \\
\hline \multirow{3}{*}{7} & 2015 & \multirow{3}{*}{ UNVR } & Rp $15,729,945,000$ & 23.47883206 \\
\hline & 2016 & & Rp $16,745,695,000$ & 23.54140705 \\
\hline & 2017 & & $\operatorname{Rp} 18,906,413,000$ & 23.66276701 \\
\hline \multirow{3}{*}{8} & 2015 & \multirow{3}{*}{ SMCB } & Rp $17,321,565,000$ & 23.57521809 \\
\hline & 2016 & & Rp 19,763,133,000 & 23.70708407 \\
\hline & 2017 & & Rp 19,626,403,000 & 23.70014159 \\
\hline
\end{tabular}


Lampiran 8

Perhitungan Ukuran Perusahaan USD

\begin{tabular}{lllrll}
\hline No & Tahun & Kode & Total Aset & & Ukuran Perusahaan \\
\hline \multirow{3}{*}{1} & 2015 & & & $\$ 2,683,873$ & 14.80277146 \\
& 2016 & TKIM & $\$ 2,491,282$ & 14.728308 \\
& 2017 & & $\$ 2,580,875$ & 14.76363905 \\
2 & 2015 & & & $\$ 312,994,597.00$ & 19.56169649 \\
2 & 1026 & GMFI & $\$ 442,589,107.00$ & 19.90815237 \\
& 2017 & & $\$ 539,150,882.00$ & 20.10550602 \\
\hline
\end{tabular}

Lampiran 9

Perhitungan Komite Audit

\begin{tabular}{|c|c|c|c|}
\hline No & Tahun & Kode & Komite Audit \\
\hline \multirow{4}{*}{1} & 2015 & & 13 \\
\hline & 2016 & SMGR & 21 \\
\hline & 2017 & & 18 \\
\hline & 2015 & & 16 \\
\hline \multirow[t]{3}{*}{2} & 2016 & WTON & 18 \\
\hline & 2017 & & 12 \\
\hline & 2015 & & 6 \\
\hline \multirow[t]{3}{*}{3} & 2016 & MLBI & 6 \\
\hline & 2017 & & 5 \\
\hline & 2015 & & 5 \\
\hline \multirow[t]{3}{*}{4} & 2016 & TKIM & 5 \\
\hline & 2017 & & 5 \\
\hline & 2015 & & 33 \\
\hline \multirow[t]{3}{*}{5} & 2016 & CPIN & 31 \\
\hline & 2017 & & 32 \\
\hline & 2015 & & 9 \\
\hline \multirow[t]{3}{*}{6} & 2016 & ASII & 7 \\
\hline & 2017 & & 7 \\
\hline & 2015 & & 4 \\
\hline \multirow[t]{3}{*}{7} & 2016 & INTP & 4 \\
\hline & 2017 & & 4 \\
\hline & 2015 & & 4 \\
\hline \multirow[t]{3}{*}{8} & 2016 & UNVR & 4 \\
\hline & 2017 & & 4 \\
\hline & 2015 & & 6 \\
\hline \multirow[t]{3}{*}{9} & 2016 & SMCB & 5 \\
\hline & 2017 & & 5 \\
\hline & 2015 & & 10 \\
\hline \multirow[t]{2}{*}{10} & 2016 & GMFI & 8 \\
\hline & 2017 & & 6 \\
\hline
\end{tabular}


Lampiran 10

Perhitungan Dewan Komisaris Independen

\begin{tabular}{|c|c|c|c|c|c|}
\hline No & Tahun & Kode & DKI & Dewan Komisaris & Hasil Pengukuran DKI \\
\hline & 2015 & & 2 & 7 & 0.285714286 \\
\hline \multirow[t]{3}{*}{1} & 2016 & SMGR & 2 & 7 & 0.285714286 \\
\hline & 2017 & & 2 & 7 & 0.285714286 \\
\hline & 2015 & & 2 & 6 & 0.333333333 \\
\hline \multirow[t]{3}{*}{2} & 2016 & WTON & 2 & 7 & 0.285714286 \\
\hline & 2017 & & 3 & 6 & 0.500000 \\
\hline & 2015 & & 4 & 7 & 0.571429 \\
\hline \multirow[t]{3}{*}{3} & 2016 & MLBI & 4 & 7 & 0.571429 \\
\hline & 2017 & & 3 & 6 & 0.500000 \\
\hline & 2015 & & 3 & 6 & 0.500000 \\
\hline \multirow[t]{3}{*}{4} & 2016 & TKIM & 3 & 6 & 0.500000 \\
\hline & 2017 & & 3 & 6 & 0.500000 \\
\hline & 2015 & & 2 & 6 & 0.333333 \\
\hline \multirow[t]{3}{*}{5} & 2016 & CPIN & 2 & 4 & 0.500000 \\
\hline & 2017 & & 1 & 3 & 0.333333 \\
\hline & 2015 & & 4 & 11 & 0.363636 \\
\hline \multirow[t]{3}{*}{6} & 2016 & ASII & 4 & 12 & 0.333333 \\
\hline & 2017 & & 4 & 12 & 0.333333 \\
\hline & 2015 & & 3 & 7 & 0.428571 \\
\hline \multirow[t]{3}{*}{7} & 2016 & INTP & 3 & 7 & 0.428571 \\
\hline & 2017 & & 3 & 7 & 0.428571 \\
\hline & 2015 & & 0 & 5 & 0.000000 \\
\hline \multirow[t]{3}{*}{8} & 2016 & UNVR & 0 & 5 & 0.000000 \\
\hline & 2017 & & 0 & 5 & 0.000000 \\
\hline & 2015 & & 3 & 7 & 0.428571 \\
\hline \multirow[t]{3}{*}{9} & 2016 & SMCB & 3 & 7 & 0.428571 \\
\hline & 2017 & & 3 & 7 & 0.428571 \\
\hline & 2015 & & 0 & 4 & 0.000000 \\
\hline \multirow[t]{2}{*}{10} & 2016 & GMFI & 0 & 4 & 0.000000 \\
\hline & 2017 & & 1 & 3 & 0.333333 \\
\hline
\end{tabular}

Lampiran 11

Perhitungan Sustainability Report Indeks GRI

\begin{tabular}{|c|c|c|c|c|c|}
\hline No & Tahun & Kode & Jumlah Item yang Diungkapkan & Indeks GRI & SR \\
\hline & 2015 & & 32 & 91 & 0.351648352 \\
\hline \multirow[t]{3}{*}{1} & 2016 & SMGR & 19 & 91 & 0.208791209 \\
\hline & 2017 & & 8 & 91 & 0.087912088 \\
\hline & 2015 & & 22 & 91 & 0.241758242 \\
\hline \multirow[t]{3}{*}{2} & 2016 & WTON & 10 & 91 & 0.10989011 \\
\hline & 2017 & & 9 & 91 & 0.098901099 \\
\hline & 2015 & & 30 & 91 & 0.32967033 \\
\hline \multirow[t]{3}{*}{3} & 2016 & MLBI & 15 & 91 & 0.164835165 \\
\hline & 2017 & & 18 & 91 & 0.197802198 \\
\hline & 2015 & & 61 & 91 & 0.67032967 \\
\hline \multirow[t]{3}{*}{4} & 2016 & TKIM & 63 & 91 & 0.692307692 \\
\hline & 2017 & & 51 & 91 & 0.56043956 \\
\hline & 2015 & & 23 & 91 & 0.252747253 \\
\hline \multirow[t]{3}{*}{5} & 2016 & CPIN & 22 & 91 & 0.241758242 \\
\hline & 2017 & & 26 & 91 & 0.285714286 \\
\hline & 2015 & & 18 & 91 & 0.197802198 \\
\hline \multirow[t]{3}{*}{6} & 2016 & ASII & 20 & 91 & 0.21978022 \\
\hline & 2017 & & 16 & 91 & 0.175824176 \\
\hline & 2015 & & 39 & 91 & 0.428571429 \\
\hline \multirow[t]{3}{*}{7} & 2016 & INTP & 12 & 91 & 0.131868132 \\
\hline & 2017 & & 14 & 91 & 0.153846154 \\
\hline & 2015 & & 15 & 91 & 0.164835165 \\
\hline \multirow[t]{3}{*}{8} & 2016 & UNVR & 15 & 91 & 0.164835165 \\
\hline & 2017 & & 17 & 91 & 0.186813187 \\
\hline & 2015 & & 49 & 91 & 0.538461538 \\
\hline \multirow[t]{3}{*}{9} & 2016 & SMCB & 32 & 91 & 0.351648352 \\
\hline & 2017 & & 33 & 91 & 0.362637363 \\
\hline & 2015 & & 53 & 91 & 0.582417582 \\
\hline \multirow[t]{2}{*}{10} & 2016 & GMFI & 55 & 91 & 0.604395604 \\
\hline & 2017 & & 32 & 91 & 0.351648352 \\
\hline
\end{tabular}




\section{DAFTAR PUSTAKA}

Adhipradana, F., \& Daljono. (2014). Pengaruh Kinerja Keuangan, Ukuran Perusahaan dan Good Corporate Governance Terhadap Sustainability Report. Jurnal Skripsi S1 Jurusan Akuntansi Fakultas Ekonomika dan Bisnis Universitas Diponegoro.

Arum, P., \& Puspitaningrum, A. (2012). Pengaruh Karakteristik Perusahaan Terhadap Pengungkapan Internet Financial and Sustainability Reporting (ISFR). Jurnal Skripsi S1 Fakultas Ekonomi dan Bisnis Universitas Brawijaya Malang.

Bukhori, M. R. T. (2017). Pengaruh Pengungkapan Sustainability Report Terhadap Kinerja Keuangan. Jurnal Skripsi. STIE STAN.

Dewi, N. N. K., \&Jati, I. K. (2014). Pengaruh Karakter Eksekutif, Karakteristik Perusahaan, dan Dimensi Tata Kelola Perusahaan yang Baik Pada Tax Avoidance di Bursa Efek Indonesia. Jurnal Skripsi S1 Fakultas Ekonomi dan Bisnis Universitas Udayana Bali.

Dilling, P. (2010). Sustainability Reporting In A Global Context: What Are The Characteristics Of Corporation That Provide High Quality Sustainability Reports-An Empirical Analysis. International Business \& Economics Research Journal, 9 (1).

Fahmi, I. (2012). Analisis Kinerja Keuangan. Bandung: Alfabeta

Handayani, R. (2017). Pengaruh Return on Assets (ROA), Leverage dan Ukuran Perusahaan Terhadap Tax Avoidance Pada Perusahaan Perbankan yang Listing di BEI Periode Tahun 2012-2015. Jurnal Skripsi S1 Fakultas Ekonomi Universitas Kristen Maranatha Bandung.

Khafid, M. \& Aniktia, R. (2015). Pengaruh Mekanisme Good Corporate Governance dan Kinerja Keuangan Terhadap Pengungkapan Sustainability Report. Jurnal Skripsi. Universitas Negeri Semarang.

Kurniasih, T., \& Sari, M. M. R. (2013). Pengaruh Return on Assets, Leverage, Corporate Governance, Ukuran Perusahaan dan Kompensasi Rugi Fiskal Pada Tax Avoidance. Jurnal Skripsi S1 Fakultas Ekonomi dan Bisnis Universitas Udayana Bali.

Maharani, I. G. A. C., \& Suardana, K. A. (2014). Pengaruh Corporate Governance, Profitabilitas dan Karakteristik Eksekutif Pada Tax Avoidance Perusahaan Manufaktur. Jurnal Skripsi S1 Fakultas Ekonomi dan Bisnis Universitas Udayana Bali.

Nasir, A. E. I., \& Utara, V. I. (2014). Pengaruh Karakteristik Perusahaan dan Corporate Governance Terhadap Pengungkapan Sustainability Report pada Perusahaan LQ45 yang Terdaftar. Jurusan Akuntansi Fakultas Ekonomi Universitas Riau.

Puspitaningrum, A., \& Prastiwi, A. (2013). Pengaruh Karakteristik Perusahaan terhadap Internet Financial and Sustainability Reporting (IFSR). Jurnal Akuntansi Fakultas Ekonomi dan Bisnis Universitas Brawijaya.

Putri, C. D. (2013). Pengaruh Corporate Governance dan Karakteristik Perusahaan Terhadap Pengungkapan Tanggung Jawab Sosial Perusahaan dalam Sustainability Report. Jurnal Skripsi. Fakultas Ekonomi Universitas Negeri Padang.

Rifandi, A. (2017). Pengaruh Ukuran Perusahaan, Profitabilitas dan Leverage Terhadap Pengungkapan Sustainability Report (Studi Empiris Pada Perusahaan-Perusahaan yang Terdaftar di BEI Periode 2013-2015). Jurnal Skripsi S1 Fakultas Ekonomi Univeritas Negeri Padang.

Rudianto. (2013). Akuntansi Manajemen Informasi untuk Pengambilan Keputusan Strategis. Jakarta: Erlangga

Saputro, D. A. F. \& Agustina, L. (2013). Pengaruh Kinerja Keuangan Terhadap Pengungkapan Sustainability Report Perusahaan di Bursa Efek Indonesia. Jurnal Skripsi. Universitas Negeri Semarang.

Sari, M. P. Y. \& Marsono. (2013). Pengaruh Kinerja Keuangan, Ukuran Perusahaan dan Corporate Governance Terhadap Pengungkapan Sustainability Report. Journal of Accounting Diponegoro. 2(3).

Sartono, A. (2008). Manajemen Keuangan Teori, dan Aplikasi. Yogyakarta: BPFE Yogyakarta 
Soelistyoningrum, J. N. (2011). Pengaruh Pengungkapan Sustainability Report Terhadap Kinerja Keuangan. Skripsi S1 Jurusan Akuntansi fakultas Ekonomi Universitas Diponegoro Semarang.

Suryono, H \& Prastiwi, A. (2010). Pengaruh Karakteristik Perusahaan dan Corporate Governance terhadap Praktik Pengungkapan Sustainability Report. Jurnal Simposium Nasional Akuntansi XIV Banda Aceh,21-22.Juli 2011.

Wibowo. (2010). Manajemen Kinerja. Edisi keempat. Jakarta: Rajawali Pers

Widianto, H. S. (2011). Pengaruh Profitabilitas, Likuiditas, Leverage, Aktivitas, Ukuran Perusahaan dan Corporate Governance Terhadap Pengungkapan Sustainability Report. Jurnal Skripsi S1 Fakultas Ekonomika dan Bisnis Universitas Diponegoro.

Widianto, H. U. (2011). Pengaruh Profitabilitas, Likuiditas, Leverage, Aktivitas,, Ukuram Perusahaan, dan Corporate Governance Terhadap Praktik Pengungkapan Sustainability Report (Studi pada Perusahaan yang Listed (GoPublic) di Bursa Efek Indonesia (BEI) Periode 2007-2010). Skripsi S1 Fakultas Ekonomika dan Bisnis Universitas Diponegoro Semarang.

Winata, F. (2014). Pengaruh Corporate Governance Terhadap Tax Avoidance Pada Perusahaan Yang Terdaftar di Bursa Efek Indonesia Tahun 2013. Jurnal Skripsi S1 Universitas Kristen Petra Surabaya. 